\title{
Status and habitat of the White-winged Duck Cairina scutulata
}

\author{
ANDY J. GREEN
}

\begin{abstract}
Summary
The endangered White-winged Duck Cairina scutulata was formerly widely recorded from north-east India, Bangladesh, Union of Myanmar (Burma), Thailand, Laos, Vietnam, Cambodia, Malaysia (peninsular) and Indonesia (Java and Sumatra). It was found to be "common" by British ornithologists in areas of India, Myanmar and Thailand in the early part of this century. Since then, deforestation and hunting have caused a major decline to perhaps less than $5 \%$ of its original population size. Since 1980 the species has been reliably recorded from 55 sites in seven countries, with a minimum combined population of 336 individuals. A conservation plan has been produced and implementation has begun.
\end{abstract}

\section{Introduction}

The White-winged Duck Cairina scutulata (King et al. 1975, Collar and Andrew 1988, Sibley and Monroe 1990), often known as the White-winged Wood Duck (King 1978-1979, Madge and Burn 1988), is dependent on small wetlands amidst areas of tropical moist forest in South-East Asia. It is one of the largest duck species, with males slightly larger than females (Madge and Burn 1988). The birds feed in shallow, stagnant or slow-flowing streams, ponds, swamps or ricefields, and roost and nest in nearby forest trees. C. scutulata has long been recognized as a species threatened with extinction primarily by lowland deforestation (e.g. Gee 1958, Mackenzie and Kear 1976, King 1978-1979). Increasing concern over its status recently led to a major review of current and historical data, building up a picture of its decline, habitat needs and biology (Green 1992). This information was used to make a comprehensive conservation plan for each range country (Green 1992). The work was conducted by The Wildfowl and Wetlands Trust in association with the Asian Wetland Bureau and ICBP.

This paper is based on Green (1992) and contains a condensed review of the status, habitat use and conservation needs of $C$. scutulata. It also includes an update on status information, based on data received since the publication of Green (1992). A companion paper (Green 1993) contains a comprehensive review of the biology of C. scutulata in the field. 


\section{Methods}

From the beginning of 1990 onwards, data on C. scutulata were gathered through an extensive literature search of published and unpublished sources, correspondence with an informal network of about 50 contacts working in the range countries, and by circulation of drafts to these contacts for comments, corrections and additional information. The reliability of each record was assessed, and only records considered sound were mapped and used for habitat analyses. Descriptions given by authors and correspondents of habitats frequented by $C$. scutulata were collated to study habitat use. The positions of many additional records from unknown habitats were overlaid on vegetation maps (MacKinnon and MacKinnon 1986) to establish the likely vegetation type in the localities in question. Full details of records of the species (date, precise location, geographical coordinates, number of birds, etc.) are given in Green (1992) along with the data and literature sources for the review of habitat use. The number of $C$. scutulata recorded is always small with the great majority of sightings being of one or two birds (Green 1993).

This study has established centralized monitoring of the status and distribution of $C$. scutulata. This needs to be continued as an aid to international conservation action, and information is therefore sought by The Wildfowl and Wetlands Trust on all further records (past or future) of $C$. scutulata, to be addressed to the Threatened Species Officer.

\section{Former distribution and population (1840-1980)}

Numerous records since the species's discovery in 1840 (Muller 1842) show that C. scutulata formerly had a widespread distribution in South-East Asia, with confirmed records from nine countries (Figure I) as summarized below.

\section{India}

Formerly widespread in North-East India. Recorded in Lower Assam (Hume and Marshall 1880, Baker 1897, 1929, Savage and Mackenzie 1967), Upper Assam (Baker 1908, Stevens 1914, Gee 1958, Mukherjee 1961, Scott and Mackenzie 1970, Pirie and Choudhury 1976), Arunachal Pradesh (Ali and Ripley 1948, Mukherjee 1961), Nagaland (Hume 1890, Hutchinson 1946), Manipur (Huggins 1913, 1933. Abdulali 1968), Meghalaya (Hume 1890) and Tripura (Mitra 1957). Possible records from Madhya Pradesh (Young 1900), Chota Nagpur (Baker 1897) and West Bengal (Inglis et al. 1920). Formerly "common" in Lakhimpur and Dibrugarh Districts, Upper Assam (Hume and Marshall 1880), and the fourth commonest wildfowl species in forest jheels of the Sadiya Frontier Tract (Upper Assam) during the Palaearctic winter when this area is visited by large numbers of migrants (Parsons 1940).

\section{Bangladesh}

Present in the Chittagong Hill Tracts (Husain 1977) with possible records in the Ganges-Brahmaputra Delta of Central Bangladesh (Hume and Marshall 1880, Simson 1882, Alexander 19 $\triangle 81$ 


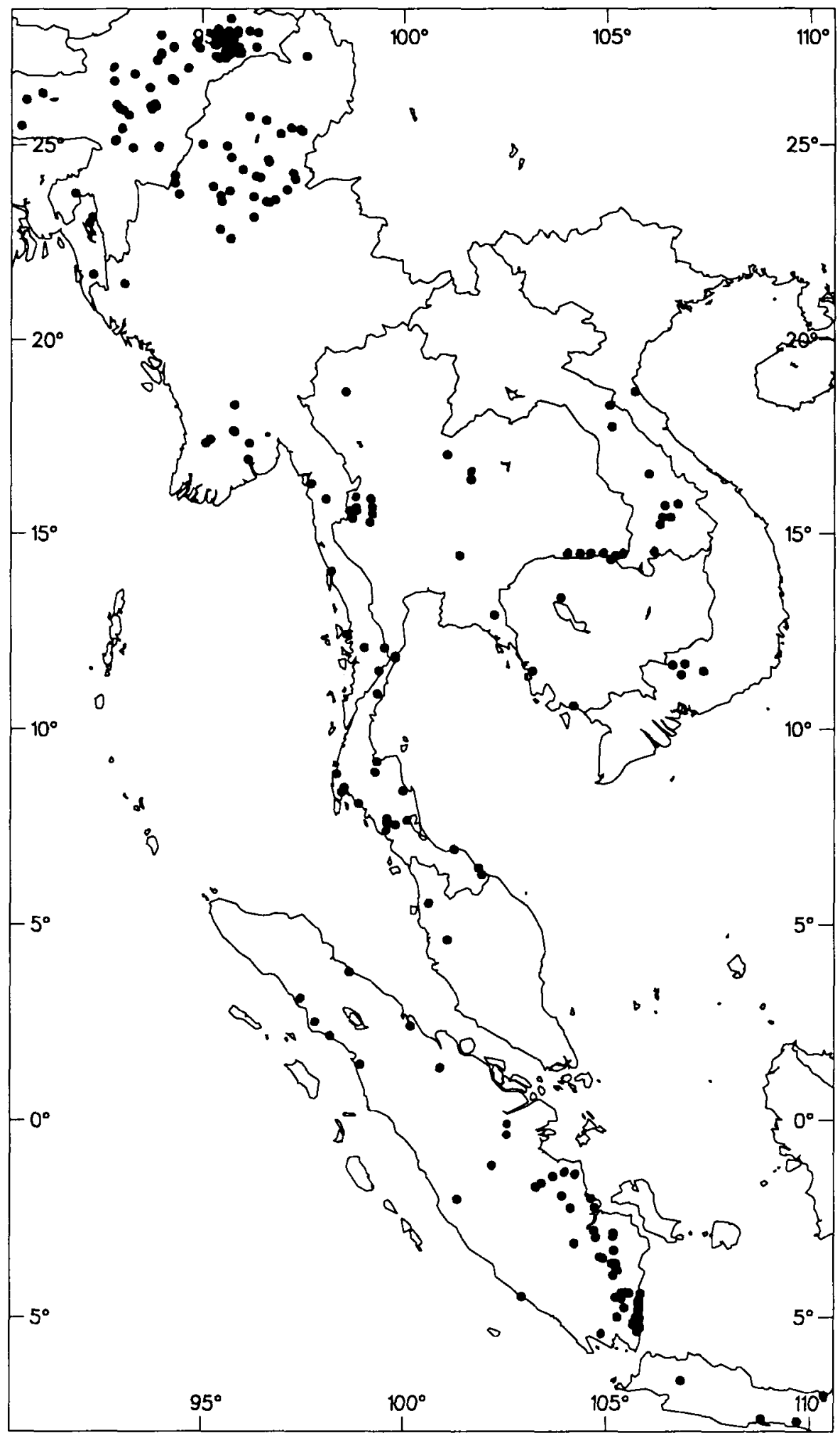

Figure 1. Former distribution of C. scutulata, showing all records from 1840 to the present day. 


\section{Union of Myanmar (Burma)}

Using the 14 regions in current usage (U Saw Han in litt. 1990), recorded from Kachin State (Evans 1901, Stanford and Ticehurst 1939, Smith 1942, Milton and Estes 1963, Tun Yin 1960, 1977), Sagaing Division (Hopwood 1908, Stanford and Ticehurst 1931, 1939, Huggins 1933, Smith 1942, Tun Yin 1960, 1977), Shan State (Smith 1942, Tun Yin 1977), Chin State (Hopwood 1912), Bago State (Stanford and Ticehurst 1931, Tun Yin 1960), Ayeyawady Division (Smith 1942), Yangon Division (Stanford and Ticehurst 1931, Stanford 1935), Mon State (Macdonald 1909, Smith 1942) and Taninthayi Division (Gould 1859, Oates 1883). Recorded from eight of the thirteen regions used by Smythies (1953): North-east Myanmar, Upper Chindwin, Northern Shan States, Central Myanmar, Arakan, Arakan Yomas, Pegu Yomas and Tenasserim. Formerly "common" in Pidaung Sanctuary, along the Mogaung River and in Upper Chindwin (Stanford and Ticehurst 1939). Also "often seen" on the Mu River and "one of the most characteristic birds of the Shweli river" (Smith 1942).

\section{Thailand}

Recorded from four of six zoogeographic regions used by Round (1988): the Peninsula (Hume 1879, Hume and Marshall 1880, Bonhote 1901, Annandale Meyer and Robinson 1906, Robinson 1909, 1915, Robinson and Kloss 1910-1911, 1918, Gyldenstope 1916, Meyer de Schauensee 1946, Gibson-Hill 1949, Medway and Wells 1976), South-west (Barton 1914), North (Deignan 1945), North-east (Deignan 1963) and South-east (S. Singhapant per P. D. Round in litt. 1990). Particularly widespread in Peninsular Thailand with records from nine provinces; "very abundant" in Trang Province (Robinson and Kloss 1910-1911) and "fairly common" in Surat Thani Province (Robinson 1915).

Laos

Recorded from Central Laos and South Laos up to 1943 (Delacour et al. 1928, Delacour 1929, Delacour and Jabouille 1931, Engelbach 1932, David-Beaulieu 1949, Dickinson 1970).

\section{Vietnam}

Recorded from North Annam and Cochinchina (Delacour et al. 1928, Delacour 1929, David-Beaulieu 1932).

\section{Cambodia}

Recorded from Kampot Province, Koh Kong, Siem Reap and Ratanakiri up to 1947 (Engelbach 1947, 1952, Thomas c. 1961). 


\section{Malaysia (Peninsular)}

Only one confirmed record, from Ipoh in Perak State before 1900 (Robinson 1909). Possible records from Kedah (Gibson-Hill 1949) and Taman Negara (Mohammad Khan bin Momin Khan per J. G. Corder verbally 1990).

\section{Indonesia}

Formerly widespread in Sumatra and Java. Recorded in seven of eight Sumatran provinces (Aceh, Sumatra Utara, Riau, Jambi, Sumatra Selatan, Lampung, Bengkulu) and in the Kerinci region, and possible record from Siberut Island west of Sumatra (Fisher 1981, Holmes 1990, Green and Crosby 1992). Recorded from West and Central Java (Green and Crosby 1992), and possible record from Sempu Island along the south coast of Java (Appelman 1940). The Indonesian population is worthy of being treated as a distinct race (Mackenzie 1990, Green 1993).

\section{Current distribution and population (since 1980)}

Records since 1980 (Figure 2) show that $C$. scutulata is still widespread in that it survives in at least seven countries, but its distribution is now highly fragmented. Some $53-63$ populations have been located since 1980 in the sites listed in Table 1 . There is currently no evidence that any of these sites holds more than 30 birds, but most sites have not been surveyed in detail.

\section{India}

Recent records from Dibrugarh, Lakhimpur, Nowgong, Silchar and Sonitpur Districts in Assam (Mackenzie 1985, B. K. Talukdar in litt. 1990, P. C. Bhattarcharjee in litt. 1990, A. K. Singh in litt. 1991, R. P. Neog in litt. 1991, M. P. S. Sidhu in litt. 1990, W. Oliver in litt. 1990, P. Singh and J. T. Mathew in litt. 1992, Choudhury 1993a,b, H. S. A. Yahya in litt. 1993) and Tirap, Siang and Dibang Valley Districts in Arunachal Pradesh (Scott 1989, Singh 1989, Choudhury 1990, Ripley et al. 1991, R. P. Neog in litt. 1991, N. P. Pandya in litt. 1991, K. D. Choudhury in litt. 1991, A. S. Dehingia in litt. to R. B. Magor 1992). The report of a flock of over 200 by Ripley et al. (1991) is completely inconsistent with the biology of the species (Green 1993), and is likely to be an error.

\section{Bangladesh}

Recent records from the northern (Khan 1986) and southern Chittagong Hill Tracts (S. M. A. Rashid in litt. 1990).

\section{Union of Myanmar (Burma)}

Birds recently collected from Taninthayi Division just across the border with Prachuap Khiri Khan Province, Thailand (B. Stewart-Cox verbally 1991). Also a possible record from Bago State (U Saw Han in litt. 1991). 


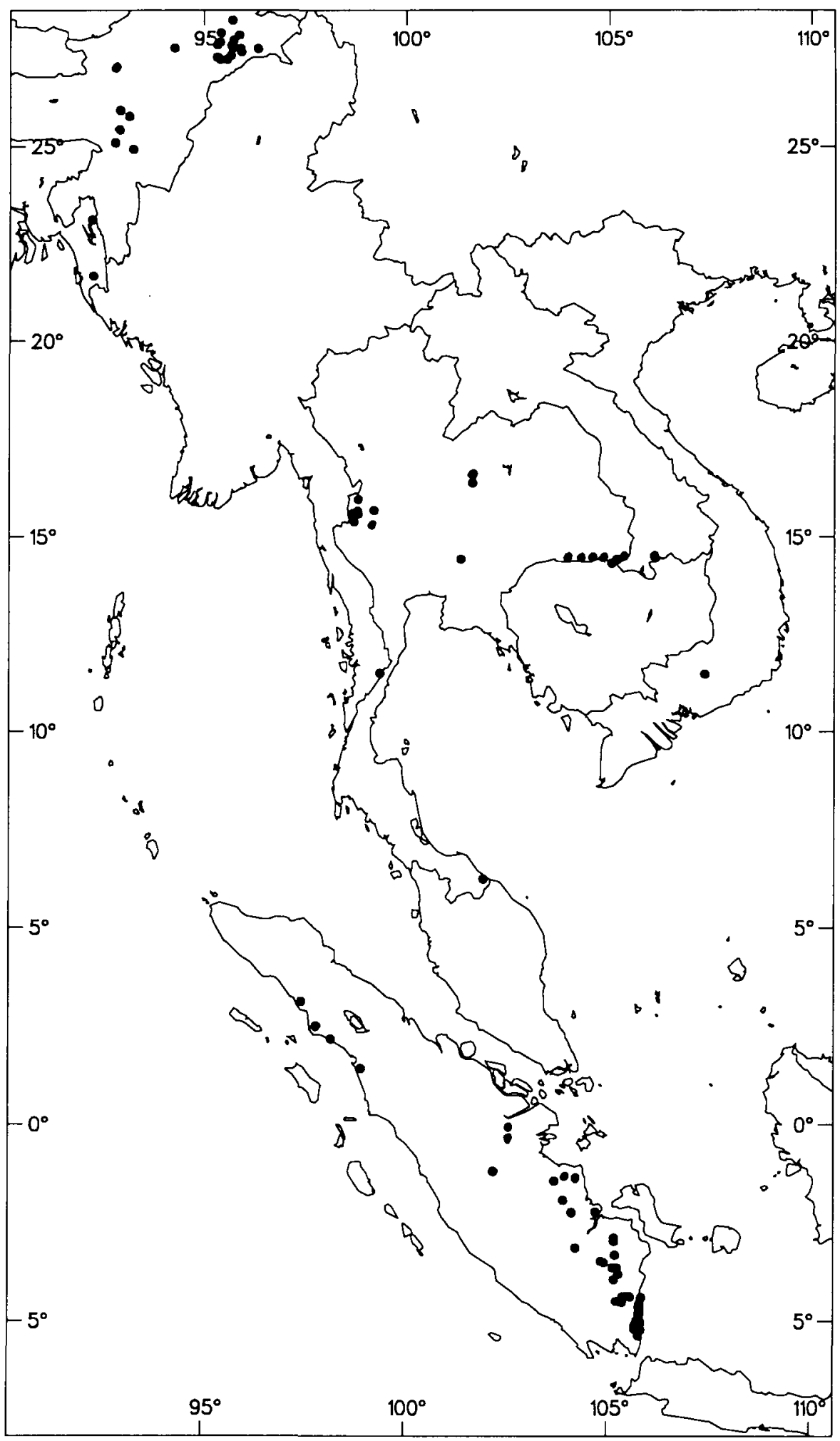

Figure 2. Current distribution of C. scutulata, showing all records from 1980 to the present day. 
Table 1. Sites where C. scutulata has been recorded since 1980 with minimum estimates of adult population size at each site (number of individuals seen or field workers' own minimum estimates).

INDIA

1. Dibru-Saikhowa WS, Assam

20

2. Nam Dapha NP, Arunachal Pradesh

3. D'Ering Memorial WS, Arunachal Pradesh

4. Nameri WS, Assam

5. Doom Dooma RF, Assam

6. Joypur RF, Assam

7. Kumsong RF, Assam

8. Lumding/Kopili river, Assam

9. Phillobari RF, Assam

10. Jiri RF, Assam

11. Subansiri river, Assam

12. Bogapani, Assam

13. Namchick RF, Assam

14. Kukurmara RF, Assam

15. Duarmara RF, Assam

16. Buridihing RF, Assam

17. Dihangi, Assam

18. Dangori RF, Assam

19. Dirok, Arunachal Pradesh

20. Dhulajan, Assam

[North Cachar Hill and Barail RF, Assam]

[Mahao WS, Arunachal Pradesh]

BANGLADESH (Chittagong Hill Tracts)

1. Pablakhali WS

2. Sanga-Matamuhuri Valley RF

MYANMAR

1. Taninthayi Division, next to Thai border

[Proposed Bago Yomas NP, Bago State]

THAILAND

1. Thung Yai WS-Huai Kha Khaeng WS, SWT

2. Umphang WS, SWT

3. Phu Khieo WS, NET

4. Nam Nao NP, NET

5. Huai Sala WS, NET

6. Phu Jong Na Yoy NP, NET

7. Khao Phanom Dongrak WS, NET

8. Yot Dom WS, NET

9. Pa Phru WS, PT

10. Khao Yai NP, NET

11. Khao Phra Vihan, NET

[Khao Soi Dao WS, SET]

[Ao Phang-nga NP, PT]

[Thaleban NP, PT]

[Sanambin NHA, NET]

LAOS (South)

1. Xe Pian proposed protected area

VIETNAM (Cochinchina)

1. Nam Bai Cat Tien NP

CAMBODIA

[Preah Vihea kouprey reserve]

MALAYSIA (Johore State)

[Kota Tingii Waterfalls] 


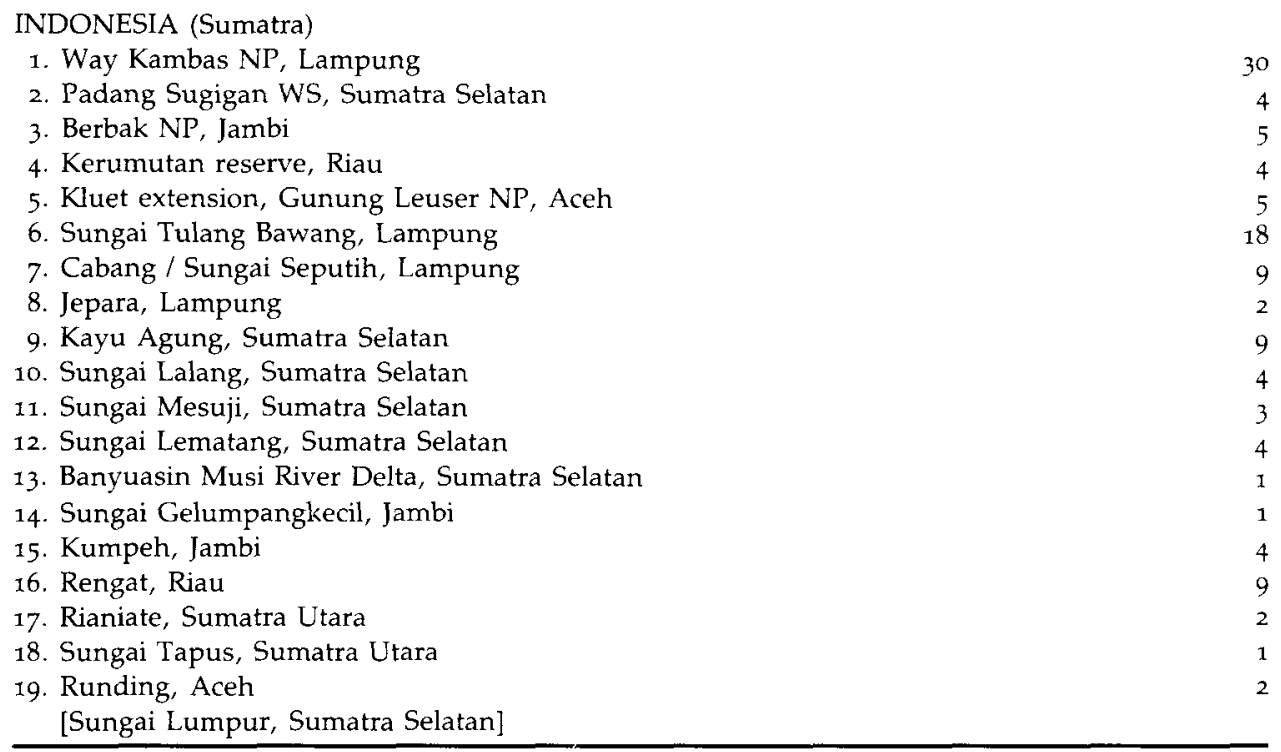

WS, wildlife sanctuary; NP, national park; RF, reserve forest; NHA, non-hunting area; PT, peninsular Thailand; NET, north-east Thailand, etc; [ ], possible sites where C. scutulata has recently been reported but there exists reasonable doubt over the reliability of the report.

\section{Thailand}

Recent records from the south-west, north-east and the Peninsula (Boonchai et al. 1986, Robson 1988, B. Stewart-Cox in litt. 1988, Round 1988, 1990, Scott 1989, Gretton 1990, Nakhasathien and Stewart-Cox 1990, P. D. Round in litt. 1990, P. Laothong in litt. 1990, 1991, B. Amget in litt. 1990, P. Hottola in litt. 1991, J. W. K. Parr verbally 1992, Parr et al. 1993). Possible record from the south-east (P. Laothong in litt. 1991).

\section{Laos}

Recent record from Champassak State in South Laos (Anderson 1993).

\section{Cambodia}

Recently reported by Thai villagers entering the part of northern Cambodia contiguous with the Khao Phanom Dongrak hills of North-east Thailand (J. W. K. Parr in litt. 1992).

\section{Vietnam}

Recent records from Cochinchina (C. R. Robson in litt. 1990, Eames and Robson 1991). 


\section{Malaysia (Peninsular)}

Possible recent record from Johore (J. G. Corder in litt.1990).

\section{Indonesia}

Recent records from six Sumatran provinces: Lampung, Sumatra Selatan, Jambi, Riau, Sumatra Utara and Aceh (Lambert 1988, Holmes 1990, Green and Crosby 1992, Rudyanto in litt. 1992, Burn and Brickle 1992, C. P. van Schaik in litt. to M. J. Silvius 1993).

\section{Reduction in population size and distribution}

All the records of $C$. scutulata fall within a broad range of about $3,000,000 \mathrm{~km}^{2}$ (Figure 1). Available data suggest $C$. scutulata populations have variable densities of one adult bird per 50-500 ha, with densities at the lower end of this range in areas with significant hunting pressure and/or degraded habitat (Green 1992, 1993). This suggests that the original total population size of C. scutulata is likely to have been in the range of 50,000-500,000 individuals.

Records since 1980 suggest a current known world population of at least 336 individuals split between Indonesia, India, Thailand, Bangladesh, Vietnam and Laos (Table 1). In most sites the population size estimated in Table 1 is the minimum number of individuals seen. These estimates only provide a very approximate guide to the real number of birds present, and there are several sources of error.

In some sites, the pressures from habitat destruction and hunting are so great that the $C$. scutulata populations are likely to have declined further or may have been eliminated. This is particularly true of Pablakhali Wildlife Sanctuary (Bangladesh), Padang Sugihan Wildlife Sanctuary and Sungai Tulang Bawang (Indonesia). Some reports of $C$. scutulata may refer to records of the domestic Muscovy C. moschata domesticus, which is widely kept in South-East Asia. Those localities where this is considered a serious likelihood are listed as possible sites in Table 1.

For many sites (e.g. Thung Yai Wildlife Sanctuary in Thailand and Berbak National Park in Sumatra) the numbers given in Table 1 are likely to underestimate the actual numbers of $C$. scutulata present. Being a retiring and dispersed bird of forest wetlands that is largely crepuscular and nocturnal (Green 1993), C. scutulata is difficult to survey and census. Only a few sites have been surveyed in a systematic way, notably Pablakhali Wildlife Sanctuary in Bangladesh and Way Kambas National Park in Sumatra (Husain and Haque 1982, Rudyanto in litt. 1990). Additional populations of $C$. scutulata probably still survive in parts of the former range where areas of suitable but recently unsurveyed habitat still exist. In Myanmar, Cambodia and Laos, suitable habitat is known to survive in various locations that previously held C. scutulata. There are also extensive tracts of apparently suitable habitat remaining in Sumatra (Holmes 1990) in areas where the presence of the species has yet to be confirmed (Figure 3).

Taking the above factors into account, the current world population of $C$. scutulata may be as high as several thousand individuals. Nevertheless, the 


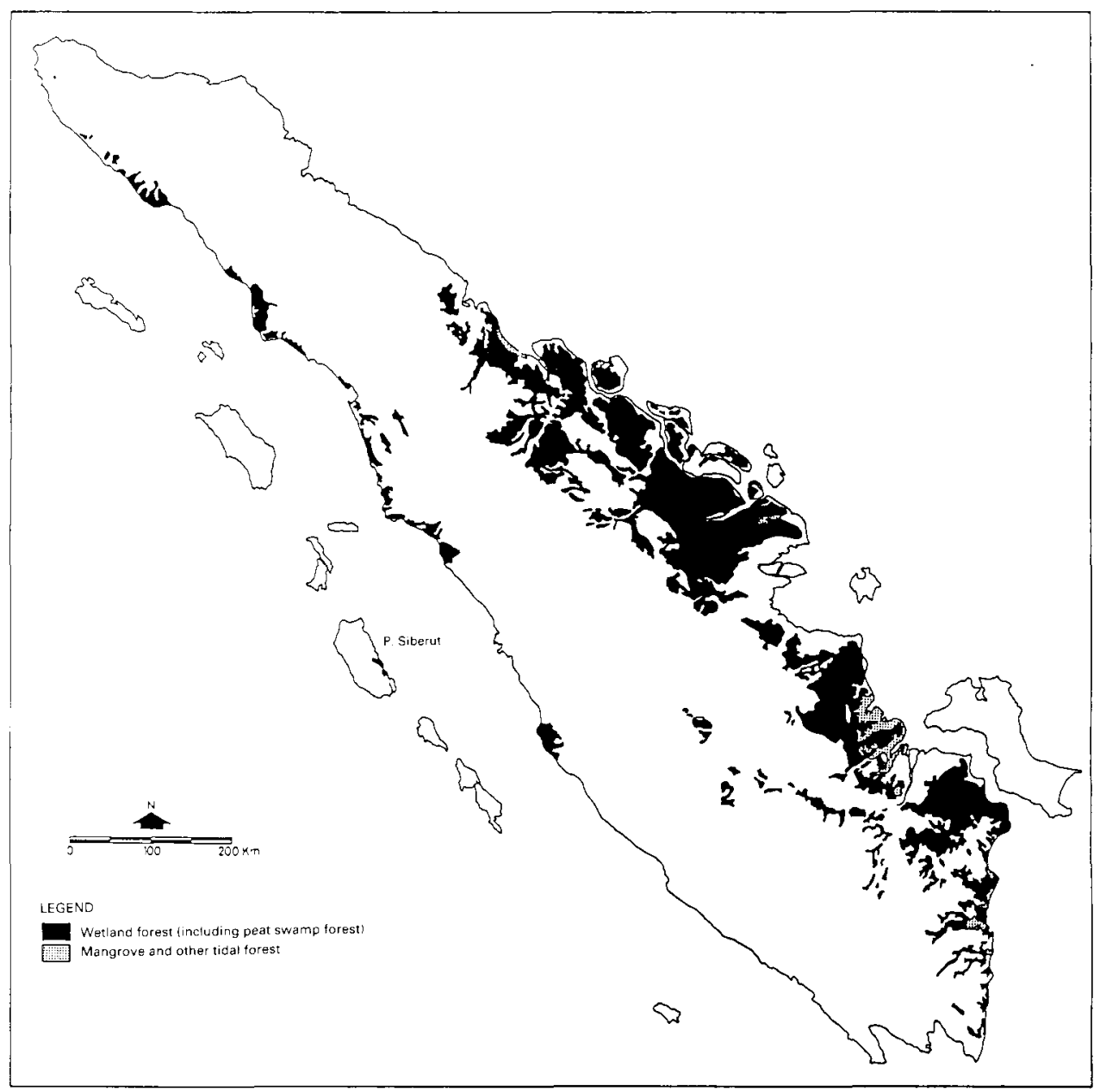

Figure 3. Current distribution of wetland forest in Sumatra (based largely on RePPProT 1988).

world population has declined markedly, possibly to less than $5 \%$ of its original size. The major change in the distribution of the species has been in the form of a marked fragmentation and a reduction in the total area actually occupied. The geographical extent of the species has probably not changed very much, and many of the differences in the current and former distributions (Figures $I$ and 2) are probably due to the species being overlooked in recent years. Nevertheless, it is likely to be extinct in Java (D. A. Holmes in litt. 1990) and Malaysia (D. R. Wells in litt. 1990).

\section{Habitat}

C. scutulata has invariably been recorded from areas containing moist tropical forest (essential for nesting and roosting) holding or providing access to stag- 
nant or slow-moving wetlands (essential for feeding). As man's impact on habitats in Asia has increased, there have been many changes to the habitats of $C$. scutulata. Thus the species is currently recorded from many areas of secondary forest. For example the majority of current known Sumatran sites for the species contain no primary forest (Lambert 1988). Breeding in secondary forest has been confirmed in southern Sumatra and Bangladesh (Husain and Haque 1982, Tim Ekspedisi 1991).

The species currently appears to be using more open, degraded habitats in Sumatra than elsewhere in its range. This is particularly true in south-east Sumatra, where most of the sites have only small patches of forest amongst grasslands and agricultural areas (Lambert 1988). In continental Asia, the great majority of records are still coming from densely forested areas. There are two likely explanations for this difference. First, many of these Indonesian sites are in the coastal plains of south-east Sumatra, and equivalent lowland plain areas on the continent are in a more advanced stage of destruction. Indeed, most have already been almost totally deforested, for example in Peninsular Thailand. In the continental plains, $C$. scutulata may have persisted for some time in similar areas of open forest habitat until the last forest patches were destroyed. Second, C. scutulata in south-east Sumatra is thought to be dependent for nesting on rengas trees (family Anonaceae), which have sap that causes skin blistering in humans. Hence these trees are often left standing when other large trees have been felled, perhaps allowing C. scutulata to survive in areas that would otherwise have been clear-felled (Lambert 1988).

\section{Topography}

The majority of $C$. scutulata records have come from lowland areas of less than $200 \mathrm{~m}$ altitude, particularly coastal plains and valley bottoms. Similarly, all the locations in which the species was formerly described as "common" (parts of Upper Assam, Myanmar and Peninsular Thailand) or appears to have been particularly widespread (e.g. south-east Sumatra) are below $200 \mathrm{~m}$. The species has also often been recorded from gentle foothills at medium elevations of 200$500 \mathrm{~m}$ (e.g. Garo Hills and Mikir Hills in India; Chittagong Hill Tracts in Bangladesh). There are also records from areas of relatively level terrain at higher altitudes, particularly plateaus holding sluggish sections of upper perennial rivers. Notable amongst these are records at $1,500 \mathrm{~m}$ on Doi Inthanon, Thailand (Deignan 1945), 1,250 m at Vijaynagar Station, Arunachal Pradesh (Ripley et al. 1991), $900 \mathrm{~m}$ in Phu Khieo Wildlife Sanctuary, Thailand (P. D. Round in litt. 1990), 900 $\mathrm{m}$ in north-west Manipur (Huggins 1913), 810 $\mathrm{m}$ at Nam Dapha National Park, Arunachal Pradesh (R. P. Neog in litt. 1990), c.700 m at Nape and over $800 \mathrm{~m}$ at Bolovens Plateau in Laos (Delacour 1929, Engelbach 1932). The highest breeding record is from over $800 \mathrm{~m}$ in Phu Khieo Wildlife Sanctuary (Round 1990). These records suggest that altitude per se is not limiting to $C$. scutulata, but rather that its main requirement is level, forested terrain with access to shallow, slow-moving or stagnant water-bodies. However, primary-forested lowlands may still have been more suitable habitat, supporting the species at higher densities, as there is no evidence of $C$. scutulata's ever being abundant at higher altitudes. 
As habitat destruction has been particularly devastating at lower altitudes, C. scutulata is now largely restricted to higher altitudes in some parts of its range. In Thailand, the species has been almost extirpated from lowland plains, and the species is currently known at 11 sites, nine of which are wholly above $100 \mathrm{~m}$ altitude (Parr et al. 1993).

\section{Forest types}

Maps of original vegetation (MacKinnon and Mackinnon 1986) were used to approximate the forest types in locations where $C$. scutulata has been recorded (Table 2). This technique only gives a guide to the dominant vegetation in a location, and should not be regarded as confirmation that the species uses forest of that class for feeding, roosting or breeding. Any forest area contains a mosaic of different vegetation types according to local conditions of moisture, soil type, orientation, etc., and C. scutulata is likely to depend on forest along wetland corridors that differs from the dominant forest type in the area. In a few cases, authors' descriptions specify the forest types where C. scutulata has been recorded (Table 2 ).

Using the vegetation classification adopted by MacKinnon and MacKinnon (1986), Table 2 shows that $C$. scutulata has been recorded from a variety of tropical moist forest types, but avoids the drier formations (e.g. tropical dry deciduous forest, dry dipterocarp forest, savanna forest, thorn scrub forest). In continental Asia the great majority of records come from tropical wet evergreen and tropical semi-evergreen forest, and both these have been used for nesting in Bangladesh (Husain and Haque 1982, Green 1993). In areas dominated by

Table 2. Forest types where C. scutulata has been reliably recorded, following the vegetation classification used by Mackinnon and Mackinnon (1986)

\begin{tabular}{|c|c|c|c|c|c|c|c|c|c|c|}
\hline & TWE & TSE & TME & MWT & TMD & MDF & MLO & FSW & PSW & MAN \\
\hline INDIA & + & + & & + & + & & & & & \\
\hline BANGLADESH & $X^{n}$ & $X^{n}$ & & & + & & & & & \\
\hline MYANMAR & + & + & & & & + & + & & & \\
\hline THAILAND & & $x$ & $x$ & & & $x$ & & $?$ & $x$ & \\
\hline LAOS & & + & + & & & & & & & \\
\hline CAMBODIA & + & $?$ & & & & $?$ & & $?$ & & \\
\hline VIETNAM & & + & & & & & & $x$ & & \\
\hline MALAYSIA & + & & & & & & & & & \\
\hline INDONESIA & $?$ & $?$ & & & & & & $X^{n}$ & $x$ & $x$ \\
\hline Total & 5 & 6 & 2 & 1 & 2 & 2 & 1 & 2 & 2 & 1 \\
\hline
\end{tabular}

+ record according to vegetation maps (MacKinnon and MacKinnon 1986).

? possible record according to vegetation maps, but location not specific enough or forest types too varied to be certain.

$X$ record confirmed by author's description of habitat use. These refer to recent records (post-1980) with the exception of TME for Thailand.

${ }^{n}$ confirmed use for nest sites.

TWE, tropical wet evergreen forest; TSE, tropical semi-evergreen forest; TME, tropical montane evergreen forest; MWT, montane wet temperate forest; TMD, tropical moist deciduous forest; MDF, mixed deciduous forest; MLO, moist lowland forest; FSW, freshwater swamp forest; PSW, peat swamp forest; MAN, mangrove. 
deciduous formations, C. scutulata appears to depend on narrow bands of gallery evergreen forest flanking watercourses (Nakhasathien and Stewart-Cox 1990).

In Indonesia most $C$. scutulata records have come from freshwater swamp and peat-swamp forest. There is only a handful of records outside swamp forest, and most or all of these are from areas with swamp forest nearby. Some Javan records may have been from evergreen forest, and several Sumatran birds have been recorded flying into mangroves (Lambert 1988, Holmes 1990). Nest-sites have been found in freshwater swamp forest (Holmes 1977). On the continent, there are only confirmed records from swamp forest at two sites (C. Robson in litt. 1990, P. Laothong in litt. 1991), and no evidence of breeding. These apparent differences in habitat use between Indonesia and continental Asia may simply reflect differences in the availability of the various habitat types. Considerable areas of swamp forest were originally present in parts of the continental range (e.g. Myanmar, Thailand, Cambodia, Vietnam), but most of these have long since been extensively cleared (MacKinnon and Mackinnon 1986).

Nesting occurs in tree holes and hollows, and the tree species used are likely to vary with availability. In Bangladesh $C$. scutulata nests have been found in civit Swintonia floribunda, a tropical wet evergreen forest species, and barta Artocarpus lakoocha, a tropical semi-evergreen forest species (Husain and Haque 1982, Green 1993). In Assam, a nest has recently been described in the top of a seasonally inundated bher tree Salix tetrasperma stump (Choudhury 1993a). In southern Sumatra, C. scutulata is thought to breed in rengas, the local name for a complex of trees of family Anonaceae (mainly genera Melanorrhoea and Gluta) found in freshwater swamp forest (Holmes 1977, Lambert 1988).

\section{Wetland types}

C. scutulata has been recorded from a variety of relatively small, shallow, sluggish or stagnant wetlands in forest areas (Table 3). Forest streams, forest pools

Table 3. Wetland types where C. scutulata has been reliably recorded

\begin{tabular}{|c|c|c|c|c|c|c|c|c|}
\hline & STR & RIV & OPE & SWA & MAR & LAK & RIC & VAR \\
\hline INDIA & + & + & $\mathrm{X}$ & $\#$ & & $\#$ & + & + \\
\hline BANGLADESH & $\#$ & & & & & \# & & \\
\hline MYANMAR & + & + & & + & + & & + & + \\
\hline THAILAND & $\#$ & & & & & $x$ & \# & \\
\hline LAOS & + & & & & + & + & & \\
\hline VIETNAM & + & & & $x$ & & + & & \\
\hline INDONESIA & & $x$ & & \# & + & \# & $x$ & \\
\hline Total & 6 & 3 & 1 & 4 & 3 & 6 & 4 & 2 \\
\hline
\end{tabular}

+ former record (pre-1980).

$X$ current record (post-1980).

\# both former and current records.

STR, forest streams and brooks; RIV, small, sluggish rivers and river pools amongst forest; OPE, wide, open rivers with little forest on banks; SWA, swamps, bheels and flooded forest; MAR, marshes or marshy clearings; LAK, forest pools or small lakes; RIC, ricefields; VAR, a variety of small stagnant wetlands: puddles, water holes, salt licks and tea waste destruction ponds. 
and small lakes, small forest rivers, marshes and ricefields are particularly important. Authors in India and Bangladesh have reported that C. scutulata prefers wetlands in particularly dense forest (e.g. "the more overgrown and sheltered in dense jungle the pool happens to be, the more likely these birds are to be found": Parsons 1940). Large, open rivers are of little importance (only one confirmed record) and there has never been a confirmed record from a large lake or reservoir even though these often occur adjacent to areas occupied by $C$. scutulata (e.g. Kaptai Reservoir in Bangladesh: Khan 1986). The largest stagnant wetlands where C. scutulata has been recorded are swamps several square kilometres in area in Sumatra (Lambert 1988). Swamps used are mainly inland, freshwater and non-acid, including some that were newly formed as forest was flooded by earthquakes or by streams changing course (Parsons 1940). However, C. scutulata has recently been recorded from areas of acidic coastal swamps in northern Sumatra (Holmes 1990). Most recent Indonesian records are within $10 \mathrm{~km}$ of areas of permanent waterlogged plain, suggesting a degree of dependence on the permanent freshwater swamps that occur in these areas (Lambert 1988).

As man's effect on forest areas has spread, C. scutulata is likely to have increased its use of artificial wetlands such as ricefields. Regular use of ricefields was recorded as early as 1910 (Robinson and Kloss 1910-1911). In south-east Sumatra most of the grassy swamps where $C$. scutulata has recently been recorded are probably man-made by logging and burning of swamp forest in seasonally inundated areas (Lambert 1988). Forest ponds in Way Kambas National Park used regularly by $C$. scutulata are also man-made where logging tracks have dammed small streams (Chambers 1990).

\section{Threats}

\section{Deforestation}

The destruction of forest habitat is the single major cause of the drastic decline in the C. scutulata population this century. Deforestation in South-East Asia has accelerated in recent decades owing to a rapid increase in economic development and local human population (Collins et al. 1991). Total forest cover in the nine C. scutulata range countries varies from $49 \%$ in Sumatra down to only $6 \%$ in Bangladesh (Collins et al. 1991). Over the whole range, about $33 \%$ of the land area remains forested and about $27 \%$ of land area is covered with forests below $900 \mathrm{~m}$ altitude. However, these figures understate the extent of destruction of C. scutulata habitat. Deforestation has been most extensive in lowland forests in coastal plains and along valley bottoms that comprise the major habitat of $C$. scutulata, as these are the first to be converted to agriculture and other uses. For example, in Peninsular Thailand, total forest cover is estimated at $22 \%$, but less than $4.7 \%$ of the original forest below $200 \mathrm{~m}$ remains, with no surviving extensive forest blocks (Round 1988). Similarly, in Java only $3 \%$ of non-montane forest remains (D. A. Holmes in litt. 1991). In Peninsular Malaysia, the widespread clearance of forest in river valley floodplains may explain the extinction of both C. scutulata and the Green Peafowl Pavo muticus (J. C. Eames in litt. 1993). 
Most of the remaining lowland forests in the C. scutulata range are secondary forests that have been felled or selectively logged at some stage. Selective logging removes many of the large, old trees used by $C$. scutulata for nesting (Khan 1986), and recently logged areas may not be able to support the species. As development pressure has intensified, rotation cycles in forest reserves and in shifting agriculture have been shortened (Collins et al. 1991), giving less chance for the forest to regenerate to a mature stage. In addition, the continuing fragmentation of remaining forests into small forest blocks may lead to the isolation of C. scutulata populations and may result in their elimination. An isolated forest block may not be large enough to support a demographically or genetically viable population of the species, and if a severe drought, epidemic or other disaster eliminates the duck population there may be little chance of recolonization. However, a limited area of open country is not a barrier to dispersal between forest areas since C. scutulata is a strong flier and birds in Way Kambas National Park, Sumatra, travel at least $6 \mathrm{~km}$ from the nearest forest across open, populated terrain to reach ricefields (Chambers 1990).

Over the whole $C$. scutulata range, deforestation is continuing at about $15,000 \mathrm{~km}^{2}$ per annum, about $1.5 \%$ of remaining forest (Collins et al. 1991). Again, this is particularly affecting lowland forests of importance for C. scutulata, and all known populations outside protected areas (and many of those inside) are at risk of being eliminated by habitat destruction within the next 25 years if no preventative action is taken. Figure 4 demonstrates this situation in Sumatra, where all forest outside protected areas is forecast to be destroyed within the next 15-25 years (M. J. Silvius in litt. 1991), leaving a small number of totally isolated protected areas of which only five are currently known to hold $C$. scutulata. This prediction assumes that areas of "Production Forest" logged under licence will be lost as, once they have been selectively logged, they are generally logged further and claimed for other uses (M. J. Silvius in litt. 1991). Deforestation and fragmentation of remaining habitat is already further advanced in continental range countries. Ongoing deforestation through illegal logging is even commonplace in many of the protected areas where C. scutulata is currently found (Khan 1986, Round 1989).

Holmes (1990) suggested that, in Sumatra, the first phase of forest clearance may actually have benefited $C$. scutulata by the creation of more feeding habitat in seasonal swamps where swamp forest was cleared. Similarly, initial deforestation in continental lowlands may conceivably have benefited the birds when there were ricefields surrounded by still vast areas of suitable forest habitat. Indeed, C. scutulata was "fairly common on ricefields" in Thailand in 1913 (Robinson 1915).

\section{Inappropriate forest management}

Deliberate burning of forest by local people during the dry season is a widespread problem affecting large areas in Thailand and elsewhere (Round 1988). It causes a gradual conversion of dense evergreen forests into drier, open deciduous forests less suitable for $C$. scutulata. Burning is concentrated at the end of the dry season when $C$. scutulata is thought to nest. In India, reserve forests have until recently been managed systematically by foresters in ways 


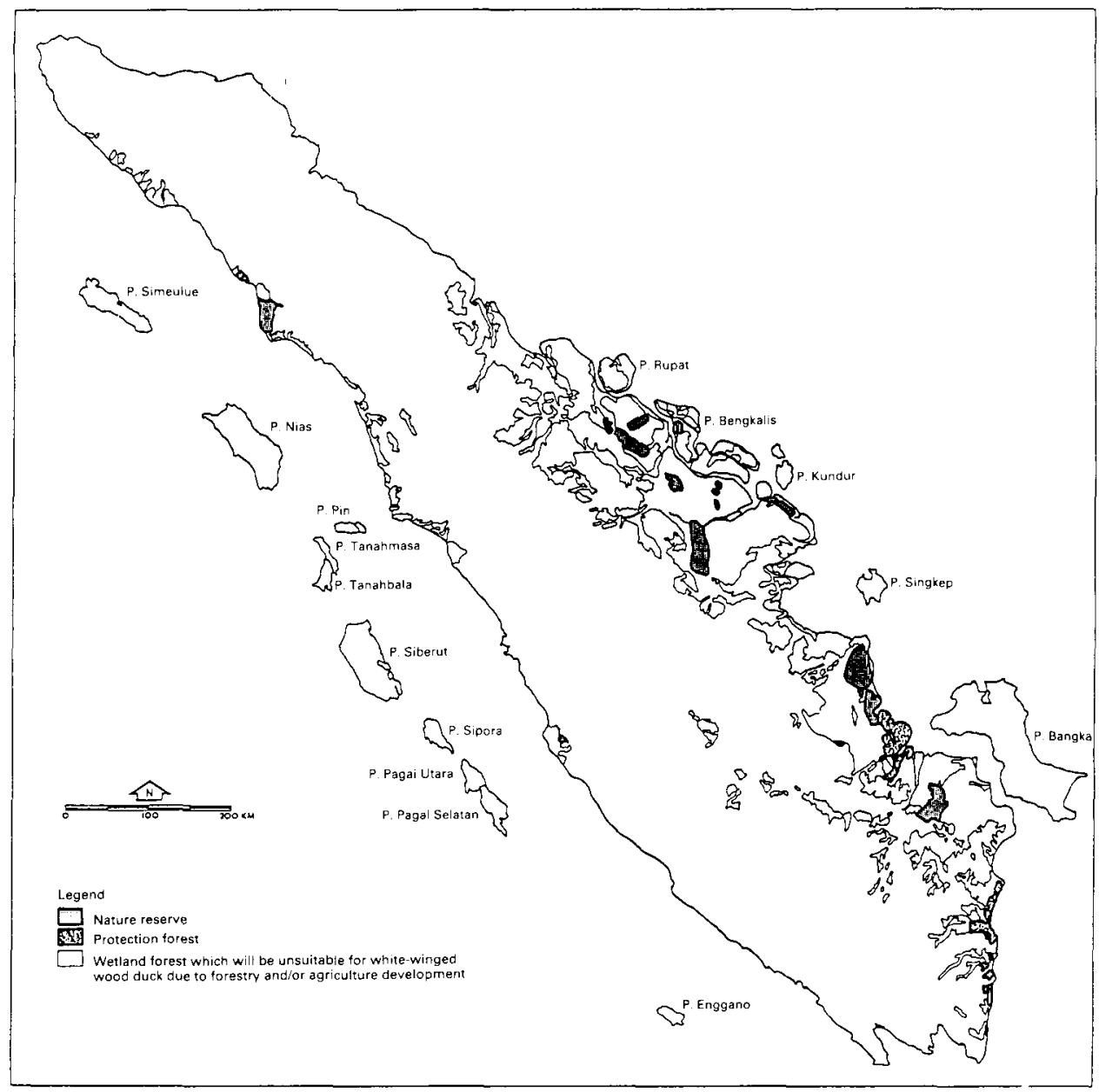

Figure 4. Future distribution of wetland forest in Sumatra, predicted to be reality by 2015 (based largely on RePPProT 1988).

harmful to $C$. scutulata: old or dead trees likely to provide nest-sites were removed, and forest marshes or swamps were drained and planted with trees (S. K. Mukherjee verbally 1991).

\section{Drainage}

There has been widespread destruction of wetlands used by C. scutulata. Swamps, marshes and other wetlands have been extensively drained, largely for agricultural use. Drainage of swamps in areas frequented by C. scutulata has been widespread in Sumatra, and there are plans to drain many more (Holmes 1990). Drainage of permanent swamps is likely to be the most serious threat, as it reduces the area of feeding habitat during the dry season when there is least available. 


\section{Hunting and trade}

The opening up and fragmentation of forests leads increasingly to encounters between $C$. scutulata and man. Being a large bird that sometimes uses ricefields and boundary areas between forest and agricultural land, $C$. scutulata is an obvious target for hunting by the rural human population. Fledged birds or ducklings have been recorded being caught by various methods: in fishing nets, with baited fishing line, tracked with dogs, shot or taken using a variety of traps and nets (Husain and Haque 1982, Lambert 1988). Eggs are also taken from the nest (Holmes 1977, Choudhury 1993a). Hunting of C. scutulata is known to occur in India, Bangladesh and Indonesia, and is a major problem within the protected areas of Thailand (Round 1988, Parr et al. 1993).

Even though most hunting of the species goes unrecorded, data from India and Bangladesh suggest that it can be intense enough to eliminate the species from forest where it would otherwise be able to survive. In Pablakhali Wildlife Sanctuary, $74 \%$ of 31 ducklings in eight broods located by Husain and Haque (1982) in 1977 and 1978 were later taken by local hunters, and two adults were taken by fishermen in the same year. The whole population of fledged birds in this area at the time was estimated at only 26 . In Dibrugarh District, Assam, in 1969, at least 26 C. scutulata were collected for food (M. J. S. Mackenzie in litt. to F. Vollmar 1969; 13 of these birds were diverted for captive breeding) when the total fledged population in the district may have been less than 100 .

There is evidence that trade in C. scutulata is also a local problem in some areas, but one nowhere near as widespread and significant as hunting. In Thailand four C. scutulata were obtained by a Thai policeman from Myanmar in the 1980 s for keeping as pets (B. Stewart-Cox verbally 1991). In Sumatra a villager was paid by a westerner for a bird and eggs in 1985 (Lambert 1988), while L. Kuah (in litt. 1991) saw four birds on sale at a Java market in 1991.

\section{Disturbance}

Whilst $C$. scutulata is a shy forest bird generally sensitive to disturbance, it has been been recorded in ricefields close to villages during the day (Holmes 1977). C. scutulata sites (including protected areas) suffer from regular encroachment by people living in or around the site and extracting logs or other forest products (bamboo, etc.), hunting, grazing cattle, fishing, etc. Whilst logging and hunting have a direct impact on C. scutulata, other activities may cause harm through disturbance, preventing the birds from feeding or breeding effectively. C. scutulata has been regularly recorded at Lake Lakatu in Thung Yai Wildlife Sanctuary, Thailand, but this site is now a regular helicopter landing site for border police who fish in the lake (B. Stewart-Cox verbally 1991). Way Kambas National Park, Sumatra, is being developed as a major tourist attraction. A new road runs alongside several forest ponds where $C$. scutulata has been regularly recorded since 1988, and causes much disturbance (Rudyanto in litt. 1991). 


\section{Pesticides}

When feeding in ricefields in recent decades, C. scutulata is certain to have encountered persistent pesticides, which are used in large quantities in SouthEast Asia. There is evidence that pesticides have played a role in major declines in storks and other wetland birds in range countries (Round 1988, P. C. Bhattarcharjee verbally 1990), and they may be having a negative impact on C. scutulata. The persistent pesticides DDT and Dieldrin were found in water samples collected from two protected areas holding C. scutulata in Thailand (Nakhasathien and Stewart-Cox 1990). In Sumatra, fishermen use pesticide cocktails to kill fish in streams and rivers that flow into Way Kambas National Park (Chambers 1990).

\section{Pollution}

In Assam, C. scutulata occurs in forest areas adjacent to tea plantations. Some wetlands in these areas are polluted with tea waste dumped with lime. $C$. scutulata has been seen using tea waste destruction ponds, especially during drought periods. A bird netted from such a pond died three days later from aspergillosis, possibly caused by the tea waste (M. J. S. Mackenzie in litt. to F. Vollmar 1969). Oil drilling and open-cast mining occur in Assam and other forested areas in the $C$. scutulata range and may cause significant pollution. Forestry activity is widespread, and effluent from timber mills may have harmful effects.

\section{Conservation measures taken}

Species protection

C. scutulata is granted legal protection from hunting, collection, etc., in five countries: Bangladesh, India, Myanmar, Thailand and Indonesia. However, there is little if any attempt to enforce this protection or to educate hunters about the law. C. scutulata is also listed on Appendix I of the Convention on International Trade in Endangered Species of Wild Fauna and Flora (CITES).

\section{Habitat protection}

A network of protected areas exists or is planned in all range countries, but lowland forest systems suitable for C. scutulata are relatively under-represented. However, at least 21 populations of the species currently occur in wildlife sanctuaries and national parks (Table 1). Dibru-Saikhowa Wildlife Sanctuary in Assam is the only protected area established because of its importance to $C$. scutulata (Mukherjee 1961). In theory, these sites give protection from habitat destruction, hunting and other forms of disturbance. In practice, poaching, illegal logging and other forms of encroachment are widespread problems. A further $11 \mathrm{C}$. scutulata populations occur in reserve forests in which hunting is forbidden but extraction of timber and other forest products is permitted. In 
practice this means that many of these sites will become unsuitable for the species in the near future.

\section{Captive breeding programmes}

Captive breeding has led to a captive population now totalling c. 280 birds spread between several countries (N. R. Hewston verbally 1991), although these are derived almost entirely from Assamese stock (Mackenzie and Kear 1976). There are currently considerable problems of disease and lack of genetic diversity in the captive population (Tomlinson et al. 1991, Cromie et al. 1992).

\section{Conclusions and recommendations}

The White-winged Duck is currently listed in the IUCN Red List as Vulnerable (WCMC 1990). Using new quantitative criteria proposed for IUCN categories by Mace et al. (1992) C. scutulata qualifies for Endangered status on the grounds that the total population is likely to be below 2,500, there are no known subpopulations with more than 250 individuals and there is a continuing decline in both the number of individuals and the area of suitable habitat.

C. scutulata has undergone a drastic decline in population size this century, and action is urgently required to reduce or prevent future declines and to allow local populations to increase. Adequate protection from habitat destruction and hunting must be provided, and habitat must be improved through appropriate management in protected areas. More data on current distribution and size of known populations are required in order to clarify which populations are largest and of highest conservation priority. Field surveys are urgently required in known sites and in other areas where $C$. scutulata may still survive. Our knowledge of the species's ecology needs to be improved. The following points give an overview of the conservation action recommendations that are presented in full in Green (1992).

(1) The following sites should be granted protection immediately, owing to their known importance to C. scutulata: Doom Dooma Reserve Forest (India), Sungai Tulang Bawang, Cabang/Sungai Seputih, Kayu Agung and Rengat (Indonesia). Following field surveys, other important sites should be granted protected status.

(2) All logging concessions granted in protected areas containing C. scutulata (e.g. Pablakhali Wildlife Sanctuary, Bangladesh) should be revoked. Tourist development in Way Kambas National Park should be carefully managed to prevent disturbance to the species.

(3) Protected area boundaries should be extended to incorporate adjacent lowland forest areas of value to $C$. scutulata. Such extensions should be considered in Dibru-Saikhowa Wildlife Sanctuary and Nam Dapha National Park in India and Phu Khieo Wildlife Sanctuary in Thailand.

(4) Old trees suitable for nesting in and around C. scutulata sites should be protected by law and left standing during any selective logging operations. In Sumatra, logging of rengas trees should be made illegal and they should 
be excluded from any legal concessions. Nest-boxes should be put up on a trial basis in secondary or degraded forest sites.

(5) Long-term field research is required into C. scutulata biology (Green 1993). A thorough understanding of the factors limiting population density or breeding success (e.g. limited availability of nest-sites, hunting or predation, limited dry season feeding habitat or territoriality) will identify management actions that will increase the size of populations.

(6) Known sites require systematic field surveys to establish the size and distribution of the C. scutulata populations. Green (1992) provides a full list of additional sites with suitable habitat in need of survey.

(7) Local education campaigns should be centred around C. scutulata sites to encourage protection and discourage hunting, using the species as a "flagship $^{\prime \prime}$ to encourage protection of the forest ecosystems.

(8) In view of the endangered status of the species in the wild, the maintenance of a captive population must currently remain a key element in C. scutulata conservation. There is a need for improved international coordination of captive breeding to ensure that the captive population functions effectively as a reserve. The Wildfowl and Wetlands Trust is seeking data from all breeding centres to establish an international studbook as an aid to genetic management.

(9) C. scutulata should be granted full specific legal protection in Vietnam, Laos and Myanmar.

The Wildfowl and Wetlands Trust and Asian Wetland Bureau are already working to implement these recommendations, but anyone who may be in a position to assist (e.g. by undertaking fieldwork) is urged to consult Green (1992) or apply to the author.

\section{Acknowledgements}

Financial assistance for this project was received from the Whitley Animal Protection Trust. The figures were prepared by Mike Crosby and Marcel Silvius. Many thanks to J. C. Eames for his referee's comments on the manuscript. I am also very grateful to the following people for providing me with data, for commenting on drafts and other varied assistance: B. Amget, P. Andrew, B. van Balen, A. Bari, D. Barooah, P. C. Bhattacharjee, L. Birch, J. M. Black, J. Bowler, H. Buck, A. Chambers, A. Choudhury, K. D. Choudhury, J. G. Corder, F. Danielsen, I. Das, G. H. W. Davison, A. S. Dehingia, R. W. R. J. Dekker, E. C. Dickinson, Le Dien Duc, A. D. Fox, U Saw Han, M. Heegaard, N. R. Hewston, D. A. Holmes, P. Hottola, T. Inskipp, M. Katti, J. Kear, S. Kamolnorranath, M. A. R. Khan, K. Komolphalin, L. Kuah, F. Lambert, P. Laothong, U Thein Lwin, M. J. S. Mackenzie, R. B. Magor, G. Morris, S. K. Mukherjee, U Pe Myint, S. V. Nash, R. P. Neog, Y. R. Noor, W. Oliver, M. Ounsted, M. Owen, J. Paine, N. P. Pandya, J. W. K. Parr, S. P. C. Pickering, C. M. Poole, Vo Quy, A. Rahmani, S. M. A. Rashid, C. R. Robson, W. A. Rodgers, P. D. Round, Rudyanto, R. E. Salter, J. A. Sayer, D. A. Scott, M. P. S. Sidhu, M. J. Silvius, A. K. Singh, P. Singh, B. Stewart-Cox, E. A. Sumardja, B. K. Talukdar, G. S. Thapliyal, A. Trombetti, W. J. M. Verheugt, M. J. Walters, D. R. Wells, A. J. Whitten, H. S. A. Yahya. 


\section{References}

Abdulali, H. (1968) A catalogue of the birds in the collection of the Bombay Natural History Society - 2. Anseriformes. J. Bombay Nat. Hist. Soc. 65: 418-430.

Alexander, H. G. (1948) White-winged Wood Duck Asarcornis scutulata (Muller) on the Padma River, East Bengal. J. Bombay Nat. Hist. Soc. 47: 749.

Ali, S. and Ripley, S. D. (1948) The birds of Mishmi Hills. J. Bombay Nat. Hist. Soc. 48: 10.

Anderson, G. (1993) Laos expedition finds Giant Ibis. Oriental Bird Club Bull. 17: 12-13.

Annandale, T. N. and Robinson, H. C., eds. (1906) Fasciculi Malayenses. London: Williams and Norgate for the University Press of Liverpool.

Appelman F. J. (1940) Poeloe Sempoe. De Tropische Natuur 29: 164-168.

Baker, E. C. S. (1897) Indian ducks and their allies, part II. J. Bombay Nat. Hist. Soc. 11: 172-198.

Baker, E. C. S. (1908) Indian ducks and their allies. First edition. Bombay: Bombay Natural History Society.

Baker, E. C. S. (1929) The fauna of British India: Birds, 6. Second edition. London: Taylor and Francis.

Barton, C. S. (1914) A short list of birds from the Raheng District. J. Siamese Nat. Hist. Soc. 1: 105-109.

Bonhote, L. J. (190I) On the birds collected by the "Skeat expedition" to the Malay Peninsula 1899-1900. Proc. Zool. Soc. London: 57-81.

Boonchai, K., Chan-Arj, T. and Maneekorn, T. (1986) [Distribution of the White-winged Wood Duck Cairina scutulata in Ubon Ratchathani Province.] Bangkok: The Seminar of Thai Fauna, Kasetsart University, 7: 10/1-8. (In Thai)

Burn, J. and Brickle, N., eds. (1992) Spirit of Sumatra 1992. Preliminary Report. Unpublished report, held at The Wildfowl and Wetlands Trust.

Chambers, A. (1990) The White-winged Wood Duck, Cairina scutulata, in the Way Kambas National Park. Unpublished report of Southampton University Expedition.

Choudhury, A. (1990) Bird observations from Namdapha National Park and adjacent areas. Arunachal Forest News 8: 38-43.

Choudhury, A. (1993a) A nesting site of the White-winged Wood Duck in Assam. IWRB Threatened Waterfowl Research Group Newsletter 3: 8.

Choudhury, A. (1993b) The White-winged Wood Duck in Dangori Reserved Forest, Assam. IWRB Threatened Waterfowl Research Group Newsletter 4: 14-15.

Collar, N. J. and Andrew, P. (1988) Birds to watch: the ICBP world check-list of threatened birds. Cambridge, U.K.: International Council for Bird Preservation (Techn. Publ. 8).

Collins, N. M., Sayer, J. A. and Whitmore, T. C., eds. (1991) The conservation atlas of tropical forests: Asia and the Pacific. London: Macmillan.

Cromie, R. L., Brown, M. J. and Stanford, J. L. (1992) The epidemiology of avian tuberculosis in White-winged Wood Ducks Cairina scutulata at The Wildfowl \& Wetlands Trust, Slimbridge Centre (1976-91). Wildfowl 43: 211-214.

David-Beaulieu, A. D. (1932) Les oiseaux de la région de Honquan. Oiseau et R.F.O. 2: 133-154.

David-Beaulieu, A. D. (1949) Les oiseaux de la province de Savannakhet (Bas-Laos). Oiseau et R.F.O. 19: 41-84.

Deignan, H. G. (1945) The birds of northern Thailand. U. S. Natn. Mus. Bull. 186.

Deignan, H. G. (1963) Checklist of the birds of Thailand. U. S. Natn. Mus. Bull. 226.

Delacour, J. (1929) On the birds collected during the fourth expedition to French Indochina. Ibis (12)5: 193-220.

Delacour, J. and Jabouille, P. (1931) Les oiseaux de l'Indochine française, 1. Paris: Exposition Coloniale Internationale. 
Delacour, J., Jabouille, P. and Lowe, W. P. (1928) On the birds collected during the third expedition to French Indochina. Ibis (12)4: 23-51.

Dickinson, E. C. (1970) Birds of the Legendre Indochina Expedition. Amer. Mus. Novit. 2423.

Eames, J. C. and Robson, C. R. (1991) Forest bird surveys in Vietnam, 1991: preliminary report. Cambridge, U.K.: International Council for Bird Preservation.

Engelbach, P. (1932) Les oiseaux du Laos Méridional. Oiseau et R.F.O. 2: 439-498.

Engelbach, P. (1947) Liste complémentaire aux oiseaux du Cambodge. Oiseau et R.F.O. 18: 5-26.

Engelbach, P. (1952) Notes de voyage dans les monts des Cardamomes (Cambodge). Oiseau et R.F.O. 22: 283-302.

Evans, G. H. (1901) On the occurrence of the White-winged Wood Duck (Asarcornis scutulatus) in Upper Burma. J. Bombay Nat. Hist. Soc. 13: 532-533.

Fisher, C. T. (1981) Specimens of extinct, endangered or rare birds in the Merseyside County Museums, Liverpool. Bull. Brit. Orn. Club 101: 276-285.

Gee, E. P. (1958) The present status of the White-winged Wood Duck, Cairina scutulata (S. Muller). J. Bombay Nat. Hist. Soc. 55: 569-574.

Gibson-Hill, C. A. (1949) An annotated check list of the birds of Malaya. Bull. Raffles Mus. 20.

Gould, J. O. (1859) List of birds collected in Tavoy, in the Tenasserim Provinces, by Captain Briggs, Deputy Commissioner of Tavoy. Proc. Zool. Soc. London: 149-150.

Green, A. J. (1992) The status and conservation of the White-winged Wood Duck Cairina scutulata. Slimbridge, Glos, U.K.: IWRB Spec. Publ. 17. (Available from IWRB for UK£10.00 plus postage and packing: £2.50 UK, £3.00 overseas).

Green, A. J. (1993) The biology of the White-winged Duck Cairina scutulata. Forktail 8: $65-82$.

Green, A. J. and Crosby, M. J. (1992) The historical range of the White-winged Wood Duck Cairina scutulata in Indonesia. Kukila 6: 1-7.

Gretton, A. (1990) Recent reports. Oriental Bird Club Bull. 11: 48.

Gyldenstolpe, N. (1916) Zoological results of the Swedish Zoological expeditions to Siam (1911)1912 and (1914)1915 IV. Birds II. Kungl. Svenska Vetenskapsakad. Handl. 56(2): 1160.

Holmes, D. A. (1977) A report on the White-winged Wood Duck in southern Sumatra. Wildfowl 28: 61-64.

Holmes, D. A. (1990) Note on the occurrence of the White-winged Wood Duck Cairina scutulata on the west coast of North Sumatra. Kukila 5: 69-72.

Hopwood, C. (1908) A further list of birds from the Chindwin, Upper Burma. J. Bombay Nat. Hist. Soc. 18: 432-433.

Hopwood, C. (1912) A list of birds from Arakan. J. Bombay Nat. Hist. Soc. 21: 1196-1221.

Huggins, J. C. (1913) Wood-duck (Asarcornis scutulata) in Manipur. J. Bombay Nat. Hist. Soc. 22: 632 .

Huggins, J. C. (1933) The game birds and animals of the Manipur state with notes on their numbers, migration and habits. J. Bombay Nat. Hist. Soc. 36: 406-422.

Hume, A. O. (1879) The birds of the western half of the Malay Peninsula. Stray Feathers 8: $151-163$.

Hume, A. O. (1890) The nests and eggs of Indian birds, 3. Second edition. London: R. H. Porter.

Hume, A. A. and Marshall, C. H. T. (1880) Game-birds of India, Burmah and Ceylon, 3. Calcutta: published privately.

Husain, K. Z. (1977) The White-winged Wood Duck. Tigerpaper 4(1): 6-8.

Husain, K. Z. and Haque, M. N. (1982) The White-winged Wood Duck Project. Dhaka: report to the University Grants Commission. 
Hutchinson, R. E. (1946) The White-winged Wood-duck, Asarcornis scutulata (Muller). J. Bombay Nat. Hist. Soc. 46: 402-403.

Inglis, C. M., Travers, W. L., O'Donel, H. V. and Shebbeare, E. O. (1920) A tentative list of the vertebrates of the Jalpaiguri District, Bengal. J. Bombay Nat. Hist. Soc. 27: 151-162.

Khan, M. A. R. (1986) The threatened White-winged Wood Duck Cairina scutulata in Bangladesh. Forktail 2: 97-101.

King, B., Woodcock, M. and Dickinson, E. C. (1975). A field guide to the birds of South East-Asia. London: Collins.

King, W. B. (1978-1979) Red data book, 2: Aves. Second edition. Morges, Switzerland: International Union for Conservation of Nature and Natural Resources.

Lambert, F. (1988) The status of the White-winged Wood Duck in Sumatra, Indonesia. A preliminary assessment. PHPA-AWB/INTERWADER Report No. 4.

Macdonald, K. C. (1909) The White-winged Wood Duck (Asarcornis scutulata) in Tenasserim. J. Bombay Nat. Hist. Soc. 19: 263.

Mace, G., Collar, N., Cooke, J., Gaston, K., Ginsberg, J., Leader Williams, N., Maunder, M. and Milner-Gulland, E. J. (1992) The development of new criteria for listing species on the IUCN Red List. Species 19: 16-22.

Mackenzie, M. J. S. (1985) Diary of M.J.S. Mackenzie: Visit to India April (1985). Unpublished report to the Wildfowl and Wetlands Trust, Slimbridge, U.K.

Mackenzie, M. J. S. (1990) White-winged Wood Duck Cairina scutulata - the question of Indonesian albinism. Wildfowl 41: 163-166.

Mackenzie, M. J. S. and Kear, J. (1976) The White-winged Wood Duck. Wildfowl 27: 5-17.

MacKinnon, J. and MacKinnon, K. (1986) Review of the protected areas system in the IndoMalayan realm. Gland, Switzerland: International Union for Conservation of Nature and Natural Resources.

Madge, S. and Burn, H. (1988) Wildfowl. London: Christopher Helm.

Meyer de Schauensee, R. (1946) On Siamese birds. Proc. Acad. Nat. Sci. Philadelphia 48: $1-98$.

Medway, Lord and Wells, D. R. (1976) Birds of the Malay Peninsula, 5. London: Witherby.

Milton, O. and Estes, R. D. (1963) Burma Wildlife Survey 1959-1960. New York: American Committee for International Wildlife Protection. (Spec. Publ. 15).

Mitra, S. N. (1957) Banglar shikar prani. Calcutta: Bengal Government Press. (In Bengali).

Mukherjee, A. K. (1961) A report on the investigation of the status of the White-winged Wood Duck in Assam and recommendations of a sanctuary for its protection. Rec. Indian Mus. 59: 471-478.

Muller, S. (1842). Verhandelingen over de Natuurlijke Geschiedenis der Nederlandsche Overzeesche Bezittingen ... Land-en Volkenkunde 1: 159, footnote (Java).

Nakhasathien, S. and Stewart-Cox, B. (1990) Nomination of the Thung Yai-Huai Kha Khaeng Wildlife Sanctuary to be a UNESCO World Heritage Site. Bangkok: Royal Forest Department.

Oates, E. W. (1883) A handbook to the birds of British Burmah including those found in the adjoining state of Karennee, 2. London: R. H. Porter.

Parr, J. W. K., Laothong, P. and Ruangsree, G. (1993) A survey of the White-winged Wood Duck in Thailand. Slimbridge, Glos, U.K.: The Wildfowl and Wetlands Trust.

Parsons, R. E. (1940) Notes on wild duck and geese in the Sadiya Frontier Tract, Assam. J. Bombay Nat. Hist. Soc. 41: 422-426.

Pirie, A. H. and Choudhury, A. H. (1976) Assam Valley Wild Life Society White-winged Wood Duck Protection Scheme. Unpublished report.

RePPProT (1988) Review of Phase I Results: Sumatra. Regional Physical Planning Programme for Transmigration, Departemen Transmigrasi, Jakarta and Land Resources Department ODNRI, London. 
Ripley, S. D., Saha, S. S. and Beehler, B. M. (1991) Notes on birds from the Upper Noa Dihing, Arunachal Pradesh, Northeastern India. Bull. Brit. Orn. Club 111: 19-28.

Robinson, H. C. (1909) Notes on birds new to, or rare in, the Malay Peninsula. J. Fed. Malay States Mus. 4: 129-133.

Robinson, H. C. (1915) On a collection of birds from the Siamese province of Bandon, North East Malay Peninsula. J. Fed. Malay States Mus. 5: 83-110.

Robinson, H. C. and Kloss, C. B. (1910-1911) On birds from the northern portion of the Malay peninsula including the islands of Langkawi and Teratau. Ibis (9)4: 659-675; (9) 5: 10-79.

Robinson, H. C. and Kloss, C. B. (1918) On a collection of birds from the province of Puket, peninsular Siam. J. Nat. Hist. Soc. Siam 3: 87-119.

Robson, C. (1988) Recent reports. Oriental Bird Club Bull. 8: 32-36.

Round, P. D. (1988) Resident forest birds in Thailand: their status and conservation. Cambridge, U.K.: International Council for Bird Preservation.

Round, P. D. (1989) Implications of the logging ban for the conservation of Thai wildlife. WWF Reports, October/November 1989.

Round, P. D. (1990) White-winged Duck. Bangkok Bird Club Bull. 7: 11.

Savage, C. D. W. and Mackenzie, M. J. S. (1967) Wetlands and wildfowl of Upper Assam. Unpublished report to IWRB, Slimbridge, U.K.

Scott, D. A. (1989) A directory of Asian wetlands. Gland, Switzerland: International Union for Conservation of Nature and Natural Resources.

Scott, R. W. and Mackenzie, M. J. S. (1970) A preliminary appreciation of forest areas in north eastern Assam possibly suitable for establishing a sanctuary for the Whitewinged Wood Duck. Unpublished report (held at the Wildfowl and Wetlands Trust, Slimbridge, U.K.).

Sibley, C. G. and Monroe, B. L. (1990) Distribution and taxonomy of birds of the world. New Haven and London: Yale University Press.

Simson, F. B. (1882) Notes on birds found near Dacca and in the surrounding district of Eastern Bengal. Ibis (4)6: 84-95.

Singh, R. L. (1989) Letter. Zoo's Print 4(12): 11.

Smith, H. C. (1942) Notes on birds of Burma. Simla: published privately.

Smythies, B. E. (1953) The birds of Burma. Second edition. Edinburgh and London: Oliver and Boyd.

Stanford, J. K. (1935) Notes on the birds of the Sittang-Irrawaddy plain, Lower Burma. J. Bombay Nat. Hist. Soc. 37: 859-889.

Stanford, J. K. and Ticehurst, C. B. (1931) The birds of the Prome District of Lower Burma. J. Bombay Nat. Hist. Soc. 34: 666-672; 35: 32-50.

Stanford, J. K. and Ticehurst, C. B. (1939) On the birds of Northern Burma. Part VI. Ibis (14)3: 211-258.

Stevens, H. (1914) Notes on the birds of Upper Assam. J. Bombay Nat. Hist. Soc. 23: 234$268,721-736$.

Thomas, W. W. (c. 1961) A preliminary list of the birds of Cambodia. Unpublished (held by E. C. Dickinson).

Tim Ekspedisi (1991) Bebek Hutan Bersayap Putih (Cairina scutulata) di Taman Nasional Way Kambas Propinsi Lampung, Sumatera, Indonesia. Jatinangor: Himpunan Mahasiswa Biologi, Universitas Padjadjaran Bandung. (In Indonesian.)

Tomlinson, C., Mace, G. M., Black, J. M. B. and Hewston, N. R. (1991) The Whitewinged Wood Duck Cairina scutulata: improving the management of a highly inbred species. Wildfowl 42: 123-133.

Tun Yin (1960) Two rare ducks from North Burma. Burmese Forester 10: 70.

Tun Yin (1977) White-winged wood duck in Burma. J. Bombay Nat. Hist. Soc. 74: 171. 
World Conservation Monitoring Centre (1990) IUCN Red List of threatened animals. Gland, Switzerland: International Union for Conservation of Nature and Natural Resources. Young, E. H. (1900) On "Indian ducks and their allies". J. Bombay Nat. Hist. Soc. 12: 572573.

ANDY J. GREEN

The Wildfowl and Wetlands Trust, Slimbridge, Gloucester, GL2 $7 B T$, U.K. 